\title{
PATOLOGI SOSIAL MASYARAKAT \\ (Studi Kasus di Kecamatan Wera-Ambalawi)
}

\author{
Ridwan dan Abdul Kader \\ Sekolah Tinggi Ilmu Hukum (STIH) Muhammadiyah Bima \\ Sahecapi13@gmail.com
}

\section{Abstrak}

Kenakalan remaja saat ini semakin lama semakin menjadijadi, keresahan masyarakat-pun terus berlanjut. Hal ini terjadi menyeluruh di Indonesia, terdengar berita dimanamana, baik media online, televisi maupun koran menyuarakan tentang tindakan kriminalitas yang dilakukan bukan hanya oleh orang dewasa namun bahkan oleh anak di bawah umur. Sungguh ironis, anak yang seharusnya menginjak usia bermain dan mengenyam pendidikan, harus berurusan dengan yang berwajib oleh perbuatan dan tindakannya. Demikian orang dewasa yang belum bahkan sudah menikah, yang seharusnya mengurus keluarga dan anak, harus mendekam dalam penjara. Kasus ini juga terjadi di Kecamatan Wera-Ambalawi sebagaimana hasil penelitian yang diperoleh penulis, yang sebagian terjadi karena tekanan, kebutuhan, pengaruh sosial atau bahkan ada yang karena hanya untuk bersenang-senang.

Keyword: Patologi Sosial, Masyarakat, Kecamatan WeraAmbalawi. 


\section{A. Pendahuluan}

\section{Latar Belakang Masalah}

Penyakit sosial atau penyakit masyarakat merupakan segala bentuk tingkah laku yang di anggap tidak sesuai dan melanggar norma-norma umum, adat istiadat, hukum serta Agama. Disebut sebagai penyakit karena gejala sosialnya yang terjadi di tengah masyarakat terus meletus dan semakin hari semakin menjadi-jadi. Dapat pula disebut sebagai struktur sosial yang terganggu fungsinya, disebabkan oleh faktor-faktor sosial. ${ }^{1}$

Instabilitas ini tentunya sangat memprihatinkan bagi kita, bagaimana tidak? Karena munculnya berbagai macam penyakit sosial akan mencederai nilai "Maja Labo Dahu" yang menjadi semboyan yang harus dipegang teguh oleh seluruh masyarakat Bima pada umumnya. Bahkan barubaru ini juga muncul semboyan baru dari Pemerintah Daerah (Bupati) yaitu "Bima Ramah" (Religius, Aman, Makmur, Amanah dan Handal), mewujudkan daerah yang aman dan damai merupakan harapan setiap orang, namun menurut hemat penulis semboyan Bima Ramah hanya wacana yang sama sekali tidak memiliki implementasi dalam kehidupan bagi masyarakat, hal ini bisa di lihat bagaimana kondisi sosial masyarakat Bima lebih khusus di Wera-Ambalawi, berbagai macam penyakit sosial bermunculan baik berupa perampokkan, pemerkorasaan, pembunuhan, perjudian, mabuk-mabukkan, konflik antar kampung dan masih banyak lagi penyakit sosial yang lainnya.

Lebih Parahnya lagi tindakan tersebut tidak hanya menjangkit kalangan masyarakat awam, bahkan masyarakat berpendidikanpun sering kali menjadi pelaku.

${ }^{1}$ Kartini Kartono, Patologi Sosial 2 Kenakalan Remaja, (Jakarta: Rajawali Pers, 1992), hlm. 4 
Fungsi pendidikan yang mestinya mencerahkan sudah dinodai oleh oknum-oknum yang tidak bertanggungjawab ini, norma-norma sudah di injak oleh oknum tersebut. Norma adat sengaja dilupakan, UU Negara seakan hanya menjadi catatan yang tidak memiliki implikasi dalam kehidupan bahkan Norma Agama dihilangkan dalam kehidupan sosial.

Seperti itu pulalah gambaran kondisi penyakit sosial yang kini berkembang di Kecamatan Wera-Ambalawi akhirakhir ini dan hampir di semua Desa terjangkit penyakitpenyakit yang sama. Adapun bentuk-bentuk penyakit sosial yang kini berkembang di Kecamatan Wera-Ambalawi adalah: Konflik antar Kampung, Miras (Tramadol), Pencurian, Pemerkosaan, Pembunuhan, perjudian dan lain sebagainya. Ironisnya lagi, fenomena itu sepertinya sudah menjadi hal yang di anggap wajar bagi sebagian masyarakat, hal ini bisa di lihat dari reaksi masyarakat ketika mendengar informasi bahkan melihat langsung kejadiannya terlihat biasa saja dan menganggap bahwa semua itu adalah gejala normal. Berangkat dari ilustrasi permasalahan di atas, penulis merasa bahwa penyakitpenyakit tersebut di atas harus di kaji secara mendalam apa yang melatar belakangi timbulnya penyakit sosial itu dan implikasinya agar segala penyakit itu dapat diminimalisir dan mendapatkan penanganan yang serius dari pihak yang berwajib. Penelitian ini berjudul: "Patologi Sosial Masyarakat Kecamatan Wera-Ambalawi"

\section{Rumusan Masalah}

Adapun yang menjadi fokus dalam Penelitian ini adalah: 1) Bagaiamanakah gambaran patologi sosial masyarakat di Kecamatan Wera-Ambalawi?, 2) Apa penyebab timbulnya patologi sosial masyarakat di 
Kecamatan Wera-Ambalawi? Dan 3) Bagaimana Model Pendekatan penyelesaian patologi sosial masyarakat di Wera-Ambalawi?

\section{Tujuan Penelitian}

Tujuan dari Penelitian: 1) Untuk mengetahui gambaran patologi Sosial masyarakat di Kecamatan WeraAmbalawi, 2) Untuk Mengetahui penyebab timbulnya patologi sosial masyarakat di Kecamatan Wera-Ambalawi, untuk mengetahui model pendekatan penyelesaian patologi sosial masyarakat di Wera-Ambalawi.

\section{Manfaat Penelitian}

a) Manfaat Teoritis

1) Mengetahui gambaran patologi sosial di Kecamatan Wera-Ambalawi

2) Mengetahui penyebab timbulnya patologi sosial masyarakat di Kecamatan Wera-Ambalawi

3) Mengetahui model pendekatan penyelesaian patologi sosial masyarakat di Wera-Ambalawi

b) Manfaat Praktis

Agar Pemerintah dapat mengambil langkah strategis untuk menyelesaikan segala macam patologi sosial, terutama Pemerintah Kecamatan Wera dan Ambalawi.

\section{B. METODE PENELITIAN}

\section{Jenis Penelitian}

Jenis Penelitian yang digunakan dalam Tulisan ini adalah Penelitian Empirik, penelitian yang berupaya mendeskripsikan dan menganalisis fenomena sosial berupa patologi sosial masyarakat kecamatan Wera-Ambalawi secara melihat secara langsung Obyek Penelitian sekaligus Mewawancarai lansung orang yang di anggap dapat 
memberikan jawaban terhadap berbagai permasalahan di atas.

\section{Pendekatan Penelitian}

Pendekatan yang digunakan dalam penelitian ini adalah pendekatan Sosiologis. Menurut Ratna pendekatan Sosiologis yaitu menganalisis manusia dalam masyarakat, dengan proses pemahaman mulai dari masyarakat ke individu. Pendekatan sosiologis juga merupakan pendekatan yang implikasi metodologinya berupa pemahaman mendasar mengenai kehidupan manusia dalam masyarakat. $^{2}$

\section{Jenis Data}

Adapun Jenis data dalam penelitian ini yakni Data primer, yaitu data lapangan yan diperoleh melalui observasi, wawancara mendalam dan terstruktur dan dokumentasi. Sumber data primer merupakan data yang dikumpulkan, di olah dan disajikan oleh peneliti dari sumber utama yang berupa kata-kata atau tindakan objek penelitian. Serta Data skunder, yaitu data pelengkap yang berfungsi melengkapi data-data yang diperlukan oleh data primer atau data utama. Yaitu data yang diperoleh melalui telaah kepustakaan serta data yang diperoleh dari dokumen dapat berupa buku-buku, makalah, arsip, koran, Jurnal serta dokumen resmi yang berhubungan dengan masalah yang diteliti.

\section{Sampel}

Pemilihan Sample dilakukan dengan metode Puspose sampling

2 Nyoman Kutha Ratna, Teori, Metode dan Teknik Penelitian Sastra (Yogyakarta: Pustaka Pelajar, 2009), hlm. 59.

Sangaji Jurnal Pemikiran Syariah dan Hukum 


\section{Analisis Data}

Berbagai pendapat mengemukakan bahwa analisis data adalah mendefinisikan data sebagai proses yang merinci usaha secara formal menemukan tema dan merumuskan ide seperti yang disarankan oleh data sebagai usaha untuk memberikan bantuan pada tema dan ide itu.

Dengan demikian, data yang terkumpul tersebut dibahasakan, ditafsirkan dan dikumpulkan secara induktif sehingga dapat diberikan gambaran yang tepat mengenai hal-hal yang sebenarnya terjadi. Mengingat penelitian ini hanya menampilkan data kualitatif, maka penulis menggunakan analisis data filosofis religius atau logika yamg senantiasa berlandaskan nilai-nilai moral. Dengan demikian, maka analisis data yang digunakan adalah metode analisis induktif. Yang dimaksud dengan analisis induktif adalah jalan berfikir dengan mengambil kesimpulan dari data yang bersifat khusus. Metode induktif adalah berangkat dari fakta-fakta khusus, peristiwaperistiwa yang konkrit, kemudian dari fakta-fakta atau peristiwa-peristiwa yang konkrit itu ditarik generalisasigeneralisasi yang mempunyai sifat umum. ${ }^{3}$

Analisis data dilakukan dengan tahapan, pengumpulan data, imput data, kategorisasi san penarikan kesimpulan.

\section{KAJIAN PUSTAKA}

\section{Tinjauan tentang Patologi Sosial}

a) Secara Bahasa

Secara bahasa berasal dari bahasa Yunani yaitu dari kata Phatos yang berarti penderitaan atau penyakit, dan Logos yang berarti ilmu. Patologi dalam Kamus

3 Sutrisno Hadi, Metodologi Penelitian, (Bandung: Rosda Karya, 1989), hlm. 42 . 
Besar Bahasa Indonesia diartikan dengan ilmu tentang Penyakit. ${ }^{4}$

\section{b) Secara Istilah}

Menurut istilah patologi merupakan cabang bidang kedokteran yang berkaitan dengan ciri-ciri dan perkembangan penyakit melalui analisis perubahan fungsi atau keadaan bagian tubuh. Bidang patologi terdiri atas patologi anatomi dan patologi klinik. ${ }^{5}$ Sedangkan kata sosial adalah berkenaan dengan masyarakat, istilah sosial sering dikaitkan dengan dengan hal-hal yang berhubungan manusia dan masyarakat, seperti kehidupan kaum miskin di kota, kehidupan kaum berada, kehidupan nelayan dan seterusnya. Sedangkan ilmu sosial adalah ilmu yang mempelajari tentang hubungan antar individu dengan individu, individu dengan kelompok, individu dengan masyarakat serta kelompok dengan kelompok lainya.

Jadi, patologi sosial adalah sebagai ilmu tentang gejala-gejala sosial yang dianggap sakit yang disebabkan oleh faktor-faktor sosial yang dapat membuat kondisi sosial mengalami instabil.

\section{Patologi Sosial Menurut Para Ahli}

Menurut Kartini Kartono Patologi sosial adalah semua tingkah laku yang bertentangan dengan norma kebaikan, stabilitas lokal, pola kesederhanaan, moral, hak milik, solidaritas kekeluargaan, hidup rukun bertetangga, disiplinkebaikan dan hukum formal.

4 Departemen Pendidikan, Pusat Bahasa Kamus Besar Bahasa Indonesia, (Jakarta: PT Gramedia, 2008), hlm. 1031.

5 https:/id.wikipedia.org/wiki/Patologi, diakses Bima, 20 September 2018, Pukul: 10:23 AM Wita.

Sangaji Jurnal Pemikiran Syariah dan Hukum 
Sedangkan menurut Sigmund Freud (1856-1939), Patologi sosial adalah perilaku menyimpang yang ditandai adanya pola-pola kepribadian yang inadekuat disertai dengan pengalaman-pengalaman atau konflik-konflik ketidaksadaran antata komponen-komponen kepribadian ide, ego dan super ego.

Dollard juga berpendapat bahwa Patologi sosial adalah penyimpangan perilaku yang disebabkan oleh adanya agresif sebagai akibat rasa frustasi yang muncul karena ketidakpuasan dalam diri sendiri. ${ }^{6}$

\section{Macam-Macam Patologi Sosial dalam Ilmu Sosiologi}

Kepincangan-kepincangan yang dianggap masalah sosial oleh masyarakat tergantung dari sistem nilai sosial masyarakat tersebut.akan tetapi, ada beberapa persoalan yang dihadapi masyarakat-masyarakat yang pada umumnya sama, yaitu sebagai berikut:

\section{a) Kemiskinan}

Kemiskinan diartikan sebagai suatu keadaan dimana seseorang tidak sanggup memelihara dirinya sesuai dengan taraf kehidupan kelompok dan juga tidak mapu memanfaatkan tenaga mental, maupun fisiknya dalam kelompok tersebut. Menurut sejarah, keadaan kaya dan miskin secara berdampingan tidak merupakan masalah sosial sampai saatnya perdagangan berkembang dengan pesat dan timbulnya nilai-nilai sosial yang baru. Pada masyarakat modern yang rumit, kemiskinan menjadi suatu masalah sosial karena sikap yang membenci kemiskinan tadi. Seseorang bukan merasa miskin karena kurang makan, pakaian atau perumahan, tetapi, karena harta miliknya dianggap

$6 \quad$ Psikologisosiyal.blogspot.com/2016/08/pengertian-patologi-sosialmenurut para. html, diakses Bima, 20 September 2018 Pukul: 10:53 AM Wita. 
tidak cukup untuk memenuhi taraf kehidupan yang ada. Hal ini terlihat di kota-kota besar di Indonesia, seperti Jakarta; seorang dianggap miskin karena tidak memiliki radio, televisi, atau mobil sehingga lama-kelamaan benda-benda sekunder tersebut dijadikan ukuran bagi keadaan sosial-ekonomi seseorang, yaitu apakah dia miskin atau kaya.

\section{b) Kejahatan}

Berdasarkan perspektif Sosiologi, kejahatan disebabkan karena kondisi-kondisi dan proses-proses sosial yang sama, yang menghsilkan perilaku-perilaku sosial lainnya. Analisis terhadap kondisi dan prosesproses tersebut menghasilkan dua kesimpulan, yaitu pertama, terdapat hubungan antara variasi angka kejahatan dengan variasi organisasi-organisasi sosial dimana kejahatan tersebut terjadi. Tinggi rendahnya angka kejahatan berhubungan erat dengan bentukbentuk dan organisasi-organisasi sosial sosial dimana kejahatan tersebut terjadi. Maka, angka-angka kejahatan dalam masyarakat, golongan-golongan masyarakat dan kelompok-kelompok sosial mempunyai hubungan dengan kondisi-kondisi dan proses-proses. Misalnya gerak sosial, persaingan serta bertentangan kebudayaan, ideologi politik, ekonomi dan seterusnya. Kedua, para ahli sosiologi berusaha untuk menentukan proses-proses yang menyebabkan seseorang menjadi penjahat. Analisis ini bersifat sosial psikologis.

\section{c) Disorganisasi Keluarga}

Disorganisasi keluarga adalah perpecahan keluarga sebagai suatu unit karena anggota-anggotanya gagal memenuhi kewajiban-kewajibannya yang sesuai dengan peranan sosialnya. Disorganisasi keluarga mungkin terjadi pada masyarakat-masyarakat sederhana 
karena kepala keluarga gagal memenuhi kebutuhankebutuhan primer keluarganyaatau mungkin karena dia menikah lagi.

Di zaman modern ini, disorganisasi keluarga mungkin terjadi karena konflik peranan sosial atas dasar perbedaan ras, agama, atau faktor sosial ekonomis. Adapun bentuk-bentuk diorganisasi keluarga menurut sosiologi antara lain:

1) Unit kegiatan yang tidak lengkap karena hubungan di luar perkawinan walaupun dalam hal ini secara yuridis dan sosial belum terbentuk suatu keluarga, bentuk ini dapat digolongkan sebagai disorganisasi keluarga sebab ayah (biologis) gagal dalam mengisi peranan sosialnya dan demikian juga halnya denga keluarga pihak ayah maupun keluarga pihak ibu.

2) Disorganisasi keluarga karena putusnya perkawinan sebab perceraian, perpisahan meja dan tempat tidur.

3) Adanya kekurangan dalam keluarga tersebut, yaitu dalam hal komunikasi antara anggota-anggotanya.

4) Krisis keluarga, karena salah satu yang bertindak sebagai kepala keluarga di luar kemampuannya sendiri meninggalkan rumah, mungkin karena meninggal dunia, di hukum atau karena peperangan.

5) Krisis keluarga yang disebabkan oleh faktor-faktor internal, misalnya karena terganggu keseimbangan jiwa salah seorang anggota keluarga

\section{d) Masalah Generasi Muda dalam Masyarakat Modern}

Masalah pribadi pada umumnya ditandai oleh dua ciri yang berlawanan, yakni keinginan untuk melawan (mislanya dalam bentuk radikalisme, delikuensi dan sebagainya) dan sikap yan apatis (misalnya penyesuaian yang membabi buta terhadap ukuran moral generasi tua). 


\section{e) Peperangan}

Peperangan mungkin merupakan masalah sosial paling sulit dipecahkan sepanjang sejarah kehidupan manusia. Masalah peperangan berbeda dengan masalah sosial lainnya karena menyangkut beberapa masyarakat sekaligus sehingga memerlukan kerjasama internasional yang kini belum berkembang dengan baik. Perkembangan teknologi yang pesat semakin memodernisasikan cara-cara berperang dan menyebabkan pula kerusakan-kerusakan yang lebih hebat masa-masa yang lampau.

\section{f) Pelanggaran terhadap Norma-Norma Masyarakat}

1) Pelacuran

Pelacuran dapat diartikan sebagai suatu pekerjaan yang bersifat menyerahkan diri kepada umum untuk melakukan perbuatan-perbuatan seksual dengan mendapatkan upah.

2) Delikuensi Anak-anak

Delikuensi anak-anak yang terkenal di Indonesia adalah masalah cross boys dan cross girl yang merupakan sebutan bagi anak-anak muda yang tergabung dalam suatu ikatan/organisasi formal atau semi formal yang mempunyai tingkah laku yang tidak disukai atau dengan kata lain melanggar norma-norma masyarakat.

Delikuensi anak-anak meliputi pencurian, perampokkan, pencopetan, penganiayaan, pelanggaran susila, penggunaan obat-obat perangsang dan mengendarai kendaraan tanpa mengindahkan norma lalulintas.

3) Alkoholisme

Masalah alkoholisme dan pemabuk pada kebanyakan masyarakat ada umumnya tidak berkisar 
pada apakah alkohol boleh atau dilarang dipergunakan. Persoalan pokoknya adalah siapa yang boleh menggukananya, dimana, kapan dan dalam kondisi yang bagaimana.

4) Homoseksualitas

Secara sosiologi, homoseksual adalah seseorang yang cenderung mengutamakan orang yang sejenis kelaminnya sebagai mitra seksual. Pria yang melakukan sikap-tindak demikian disebut homoseksual, sedangkan lesbian merupakan sebutan bagi wanita yang berbuat demikian. Hal yang berbeda dengan homoseksual adalah yang disebut transeksual. Mereka menderita konflik batiniah yang menyangkut identitas diri yang bertentangan dengan identitas sosial sehingga ada kecendrungan untuk mengubah karakteristik seksualnya. Homoseksual dapat digolongkan ke dalam tiga kategori, yakni:

- Golongan yang secara aktif mencari mitra kencan di tempat-tempat tertentu, seperti mislanya, barbar homoseksual.

- Golongan pasif, artinya yang menunggu.

- Golongan situsional yang mungkin bersikap pasif atau melakukan tindaan-tindakan tertentu. ${ }^{7}$

\section{Penyebab Terjadinya Penyakit Sosial}

a) Keadaan Keluarga yang Berantakkan (Broken Home)

Keluarga merupakan tempat dimana anak atau orang pertam kali melakukan interaksi dengan orang lain. Keluarga memiliki pengaruh yang sangat kuat dalam pembentukkan watak (perangai) seseorang. Oleh karena itulah keadaan keluarga sangat mempengaruhi

7 Soerjono Soekanto, Sosiologi Suatu Pengantar, (Jakarta: Rajawali Pers, 2012), hlm. 319-334 
perilaku orang yang menjadi anggota keluarga tersebut. Dalam keluarga yang broken home biasanya hubungan antar angota keluarga menjadi tidak harmonis. Keadaan keluarga tidak memberikan ketentraman dan kebahagiaan pada anggota keluarga. Akibatnya setiap anggota keluarga cenderung berperilaku semaunya, dan mencari kebahagiaan di luar keluarga. Sehingga normanorma sudah tidak lagi menjadi pijakkan dalam setiap perbuatannya.

\section{b) Persoalan Ekonomi}

Tidak terpenuhinya kebutuhan ekonomi dapat mendorong orang melakukan kegiatan apa saja, asal bisa memperoleh sesuatu yang dapat digunakan untuk memenuhi kebutuhan ekonominya. maka Tidak jarang orang menghalalkan segala cara untuk mendapatkan uang atau sesuatu yang dianggap data memenuhi keinginan nafsunya.

\section{c) Pelampiasaan Rasa Kekecewaan}

Sering kali orang yang kecewa dapat menimbulkan perilaku di luar kendali orang yang bersangkutan tersebut, bahkan tidak lagi menghiraukan norma-norma-norma maupun aturan kemasyarakatan. Misalnya: orang putus cinta, seorang anak yang ingin memiliki sepeda motor tetapi terpenuhi karena keadaan ekonomi yang tidak menjamin dan lain sebagainya.

\section{d) Pengaruh Lingkungan Masyarakat}

Lingkungan masyarakat merupakan factor yang sangat berpengaruh dalam kehidupan seseorang. Misalnya orang hidup dilingkungan penjudi akan cenderung ikut berjudi, peminum dan seterusnya. 


\section{e) Ketidak Sanggupan Menyerap Nilai dan Norma yang Berlaku}

Hal ini umumnya terjadi pada para pendatang baru (penduduk baru) di lingkungan yang baru. Karena ketidap sanggupannya menyerap dan memahami nilai dan norma yang berlaku di lingkungan barunya, sehingga akibat cenderung untuk melakukan sesuatu yang tidak diharapkan oleh masyarakat setempat.

\section{f) Pengaruh Kemajuan Teknologi}

Kemajuan teknologi selain membawa efek yang positif juga banyak menimbulkan dampak yang negative terutama bagi anak-anak yang masih labil yang belum bisa memanfaatkan Teknologi secara bijak. Televisi misalnya sering kali menayangkan film-film yang tidak pantas di tonton oleh anak-anak misalnya: Porno, film kekerasan dan lain sebagainya, belum lagi internet yang di era ini sudah sangat terbuka dan tidak ada dinding pemisah antara tayangan yang positif dan tayangan yang negative. ${ }^{8}$

\section{Masyarakat}

Masyarakat dalam Kamus Besar Bahasa Indonesia adalah sejumlah manusia dalam arti seluas-luasnya dan terikat oleh suatu kebudayaan yang mereka anggap sama. Dalam arti yang lebih kompleks masyarakat adalah kelompok orang yang merasa memiliki bahasa bersama, yang merasa termasuk dalam kelompok itu, atau yang berpegang pada bahasa yang sama. ${ }^{9}$ Dari definisi di atas dapat dipahami bahwa Masyarakat adalah sejumlah manusia yang hidup bersama dalam suatu wilayah tertentu,

8https://ayobelajarpemasaran.blogspot.com/2018/02/penyakit-sosialpengertian macam. html, diakser tanggal 11 Oktober 2018.

${ }_{9}$ Departemen, Pusat Bahasa. hlm. 885 . 
memiliki bahasa yang sama, kebudayaan dan lain sebagainya. Manusia pada dasarnya dilahirkan seorang diri, namun mengapa harus hidup bermasyarakat? Seperti diketahui manusia pertama, Adam, telah ditakdirkan untuk hidup bersama dengan manusia lain, yaitu istrinya yang bernama Hawa. Banyak cerita tentang yang hidup menyendiri seperti Robinson Crouse. Akan tetapi, pengarangnya tak dapat membuat suatu penyelesaian tentang hidup seorang diri tadi karena kalu dia meninggal dunia berarti riwayatnya pun akan habis pula. Maka, kemudian muncullah tokoh Friday sebagai teman Robinson Crousoe. Walaupun temannya itu pria juga, hal itu membuktikan bahwa pengarang sudah mempunyai perasaan tentang kehidupan bersama antar manusia. Begitu pula tokoh Tarzan di dalam film, Ia diberi pasangan seorang wanita sebagai teman hidupnya, berketurunan pula, dan seterusnya. ${ }^{10}$

Memang apabila manusia dibandingkan dengan makhluk hidup lainnya seperti hewan, dia tak akan dapat hidup sendiri. Seekor anak ayam, walaupun tanpa induk, mampu mencari makan sendiri; demikian pula hewanhewan lain seperti kucing, anjing, gajah dan lain sebagainya. Manusia tanpa lainnya pasti akan mati. Oleh karena manusia sebagai makhluk yang memiliki naluri untuk hidup dengan orang lain. Sejak dilahirkan manusia sudah mempunyai dua hasrat atau keinginan pokok, yaitu:

a) Keinginan untuk menjadi satu dengan manusia lain di sekelilingnya (yaitu masyarakat)

b) Keinginan untuk menjadi satu dengan suasana alam sekelilingnya. ${ }^{11}$

10 Soekanto, Sosiologi Suatu, hlm. 99

11 Ibid, 100. 
Dengan demikian, ketika ditemukan manusia yang hidupnya menyendiri atau melakukan tindakan-tindakan yang abnormal dan tidak sesuai dengan hakekat dasar manusia sebagai makhluk sosial, maka penulis berpersepti itu sebagai tindakan yang mencederai nilai-nilai dasar kemanusiaan dan manusia tersebut sudah terjangkit dengan yang namanya penyakit sosial atau patologi sosial.

\section{Hasil Penelitian dan Pembahasan}

\section{Bentuk Patologi Sosial Masyarakat Wera-Ambalawi}

Dari hasil penelitian yang dilakukan oleh penulis terkait patologi sosial masyarakat yang berada di kecamatan Wera-Ambalawi, menunjukkan bahwa ragam patologi sosial yang kini tumbuh di masyarakat Wera antara lain:

\section{a) Narkoba}

Sebagaimana yang dijelaskan oleh UU no. menjelaskan bahwa narkoba merupakan, dari hasil wawancara dengan beberapa informan penelitian diantara bapak Maskur, SH selaku Kasi Pemerintahan Camat Wera menjelaskan bahwa penyakit sosial yang sangat signifikan di kecamatan Wera hari ini adalah Narkoba sementara untuk penyakit sosial lainya belum terlalu mencolok, artinya penyakit sosial yang hampir dialami oleh seluruh desa yang berada di kecamatan Wera adalah Narkoba dalam jenis Tramadol. Meskipun dalam UU tentang narkoba tidak menyebutkan Tramadol sebagai bagian dari jenis narkoba, akan tetapi tramadol masuk dalam UU Kesehatan yang apabila dikonsumsi secara berlebihan atau melebihi dosis dari resep dokter, maka akan menyebabkan penggunanya hilang akal/mabuk dan bahkan sampai gila, bapak Maskur juga menuturkan bahwa di tahun 2017-2018 belasan orang asli dari Wera yang masuk rumah sakit jiwa karena 
mengkonsumsi tramadol. Hal senada juga dijelaskan oleh salah satu tokoh pemuda Wora bahwa penyakit sosial yang sangat menonjol di kecamatan Wera akhir-akhir ini adalah Pemakaian Tramadol, hal ini juga didukung oleh observasi yang dilakukan oleh penulis selama berada di desa Wora tidak sedikit yang menjadi pengkonsumsi dan bahkan pecandu tramadol. Berkaitan dengan dosa Narkoba sebagaimana dijelaskn oleh Allah dalam QS. Al-Baqarah: 219, sebagai berikut:

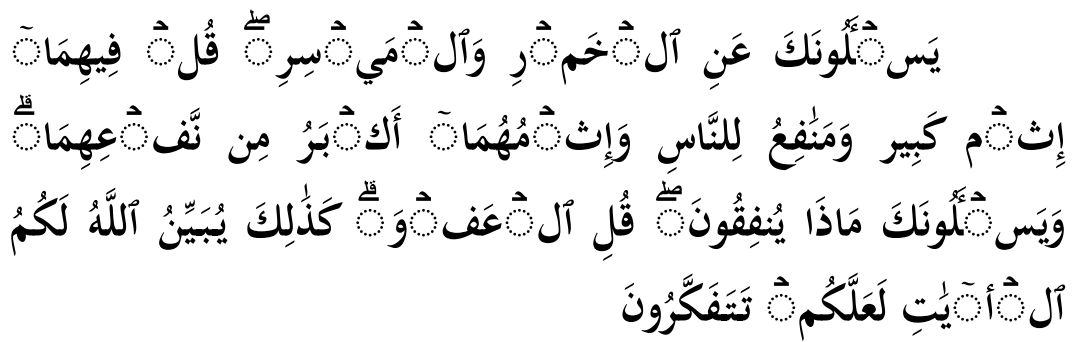

Terjemahnya:

"Mereka bertanya kepadamu tentang khamar" dan judi. Katakanlah: "Pada keduanya terdapat dosa yang besar dan beberapa manfaat bagi manusia, tetapi dosa keduanya lebih besar dari manfaatnya". dan mereka bertanya kepadamu apa yang mereka nafkahkan. Katakanlah: " yang lebih dari keperluan." Demikianlah Allah menerangkan ayat-ayat-Nya kepadamu supaya kamu berfikir."13

b) Perkelahian antar kampung dan perkelahian antar pelajar

Bentuk patologi sosial selanjutnya ialah perkelahian antar kampung. Perkelahian antar

12 Khamar sebagaimana pernyataan Amirul Mukminin 'Umar bin Khathab' dalam Mushaf Mufassir Al-Qur'an, Terjemahan, Tafsir, Tajwid adalah semua yang menutupi akal atau memabukkan.

${ }^{13}$ Departemen Agama RI, Al-Qur'an dan Terjemahannya, Surabaya: CV Fajar Mulya), 34.

Sangaji Jurnal Pemikiran Syariah dan Hukum 
kampung/peperangan merupakan penyakit sosial yang rumit di atasi sepanjang sejarah manusia karena tidak hanya melibatkan satu atau dua orang tetapi melibat banyak masyarakat, sehingga dalam menanganinya membutuhkan kerjasama nasional. ${ }^{14}$ Hal ini sesuai dengan yang dituturkan oleh bapak Kurais selaku POL PP di Camat Wera bahwa pihak kepolisian dan POL PP sering kali menghadapi perkelahian antar kampung dan merasa kewalahan dalam mengatasinya. diantara kasus perkelahian kampung antara lain: perang desa Wora dengan dusun Ntundu desa Nanga Wera, desa Wora dengan desa Tawali, desa Wora desa Bala, belum lagi perkelahian secara pribadi dari beberapa oknum. Selain perkelahian antar kampung, perkelahian antar pelajar juga sering terjadi di kecamatan Wera, salah satu sekolah yang sering melakukan tawuran adalah SMA Negeri 1 Wera dan bahkan sampai melibatkan orang kampung. Contoh kasus Siswa SMA Negeri 1 Wera yang beasal dari desa Tawali dengan siswa yang beasal dari desa Nanga Wera. Perkelahian itu berujung pemblokiran jalan Lintas Wera Bima yang dilakukan oleh keluarga korban yang berada di desa Nanga Wera.

\section{c) Pencurian}

Pencurian juga menjadi salah satu penyakit yang tumbuh dan berkembang di kecamatan Wera, mulai dari pencurian ayam, kambing sampai dengan pencurian yang lebih besar. Hasil wawancara dengan bapak Satriyo selaku BILMAS Kecamatan Wera menjelaskan bahwa pencurian adalah salah satu penyakit sosial yang meresahkan masyarakat di kecamatan Wera khususnya, dan salah satu contoh kasusnya di tahun 2019 ini adalah 
pencurian ternak kerbau di desa PAI. Pencurian dapat diartikan sebagai perbuatan yang mengambil atau memakan harta yang bukan miliknya sendiri dengan cara yang bathil, hal ini sesuai dengan firman Allah Swt. Dalam QS. Al-Baqarah: 188, sebagai berikut:

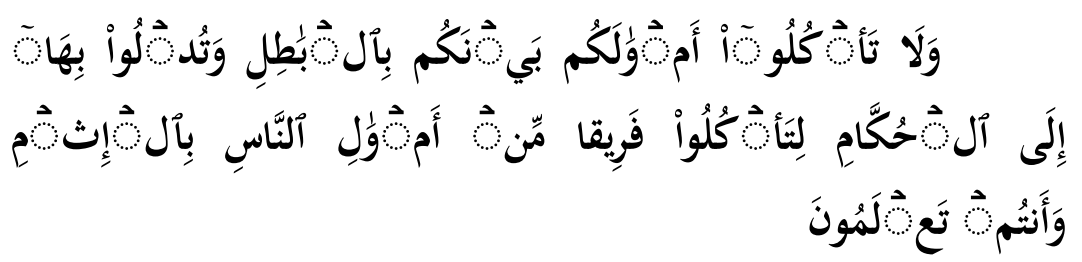

Terjemahnya:

"Dan janganlah sebahagian kamu memakan harta sebahagian yang lain di antara kamu dengan jalan yang bathil dan (janganlah) kamu membawa (urusan) harta itu kepada hakim, supaya kamu dapat memakan sebahagian daripada harta benda orang lain itu dengan (jalan berbuat) dosa, Padahal kamu mengetahui." 15

Ayat di atas memberikan peringatan kepada kita agar tidak memakan harta sesama kita dengan jalan yang tidak benar atau jalan yang bathil, artinya pencurian juga masuk dalam kategori memakan harta sesame kita dengan cara yang tidak benar, karena mencuri adalah mengambil harta yang bukan milik kita sepengetahuan pemiliknya. Selain itu ayat Al-Qur'an yang menyebutkan secara spesifik terkait pencurian tertera dalam QS. Al-Maidah ayat: 38:

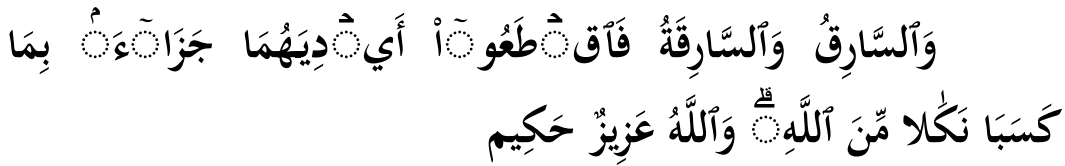

15 Departemen Agama RI, Al-Qur'an dan Terjemahannya, Surabaya: CV Fajar Mulya), 29.

Sangaji Jurnal Pemikiran Syariah dan Hukum 
Terjemahnya:

"Laki-laki yang mencuri dan perempuan yang mencuri, potonglah tangan keduanya (sebagai) pembalasan bagi apa yang mereka kerjakan dan sebagai siksaan dari Allah. dan Allah Maha Perkasa lagi Maha Bijaksana."

Mencuri adalah suatu larangan dalam Islam karena perbuatan itu sangat merugikan orang lain, seperti halnya dengan perbuatan lainnya mencuri juga merupakan perbuatan yang memiliki hukum bagi pelakunya sebagaimana telah dijelaskan secara gamblang oleh ayat di atas bahwa pencuri diperintahkan untuk di potong tangannya. ${ }^{16}$ Hukuman itu bertujuan agar pencurian menjadi jera.

Bentuk patologi sosial di atas hanyalah penyakit yang sangat signifikan terjadi di Kecamatan Wera, selain itu masih banyak lagi patologi sosial yang lainnya, dianataranya: perzinahan, aborsi, homoseksual, selarian, pernikahan dini, perceraian, KDRT dan lain sebagainya. ${ }^{17}$

\section{Faktor Pemicu Terjadinya Patologi Sosial Masyarakat Wera-Ambalawi}

Dalam setiap kasus atau kejadian, hal yang sangat mustahil ketika terjadi tanpa ada suatu sebab yang menjadi pemicu atau latar belakang terjadinya, apalagi penyakit sosial yang terjadi di tengah masyarakat Wera akhir-akhir ini, tentu ada sebab yang menjadi pemicu timbulnya penyakit sosial tersebut. Artinya setiap ada akibat pasti ada sebab yang datang terlebih dahulu karena sebab dan akibat sudah menjadi satu kesatuan yang tak terpisahkan

${ }^{16}$ Abid Rohman, Patologi Sosial Perspektif Al-Qur'an, Kajian Tafsir Tematik Sosiologi, (Uinsby, Jurnal pdf), 19.

17 Observasi, diberbagai desa kecamatan Wera. 
(Causalitas). Berikut faktor pemicu terjadinya patologi sosial masyarakat Wera, berdasarkan hasil wawancara dengan beberapa narasumber:

a) Keadaan psikologis anak yang masih labil

Pemakai Tramadol mayoritas adalah anak remaja, sehingga terbawa sampai di usia dewasanya karena sudah kecanduan. Sesuai dengan yang dituturkan oleh bapak Maskur, SH kebanyakkan yang memakai tramadol di kecamatan Wera adalah kaum muda ${ }^{18}$, dapat dipahami karena keadaan psikologis mereka masih labil, sehingga segala sesuatu ingin dicobanya apalagi remaja yang senang kumpul-kumpul dengan teman-temannya mau tidak mau ketika ada teman yang satu memakai tramadol otomatis mereka akan ikut memakainya.

b) Ekonomi

Berbeda halnya dengan pecandu/pemakai, kasus lainya terjadi pada penjual/pengedar tramadol, pengedaran tramadol disebabkan oleh factor ekonomi yang kurang bagus, kasus ini terjadi di desa Ntoke dimana salah seorang pengedar Tramadol adalah orang yang memiliki ekonomi yang kurang bagus di tambah lagi sifat malasnya bekerja sehingga dia mencari makan dengan cara yang cepat dan menguntungkan dan tidak memperdulikan halal dan haramnya yang terpenting kebutuhannya terpenuhi.

c) Rebutan Pacar

Hal sepele tetapi menyebabkan permusuhan yang berkepanjangan adalah rebutan pacar dikalangan anak remaja, salah satu penyebab terjadinya perkelahian

18 Maskur (Kasi Pemerintahan Camat Wera), Wawancara, Tanggal 20 Januari 2019.

Sangaji Jurnal Pemikiran Syariah dan Hukum 
antar pemuda adalah rebutan pacar, ${ }^{19}$ kasus ini terjadi pada $\mathrm{R}$ dengan pemuda yang berasal dari desa Nunggi. Karena berebutan pacar akhirnya mereka berkelahi dan bahkan saling dendam.

d) Menghibur diri

Tidak sedikit orang frustasi lalu menjerumuskan dirinya dalam perbuatan yang negative, seperti mabukmabukkan, bersenang dan lain sebagainya. Namun berbeda halnya dengan ibu-ibu dari desa Mawu kecamatan Ambalawi, untuk menghilang rasa bosan mereka di rumah mereka melakukan perbuatan judi dengan bermain karet. ${ }^{20}$ Mungkin kita menganggapnya hal yang biasa karena perjudiannya tidak dalam nominal yang besar, tetapi bagi penulis ini adalah bagian dari penyakit yang harus dihilangkan oleh kita, karena perjudian sekecil apapun itu adalah gejala yang tidak normal dan melanggar norma agama. 2019.

${ }^{19}$ Kurais (POL PP) dan Ita Purnamasari, Wawancara, tanggal 20 Januari ${ }^{20}$ Listiani (Pemudi desa Mawu), Wawancara, Tanggal 13 Desember 2018. 


\section{Daftar Pustaka}

Kartono, Kartini, Patologi Sosial 2 Kenakalan Remaja, (Jakarta: Rajawali Pers, 1992)

Ratna, Nyoman Kutha, Teori, Metode dan Teknik Penelitian Sastra (Yogyakarta: Pustaka Pelajar, 2009)

Hadi, Sutrisno, Metodologi Penelitian, (Bandung: Rosda Karya, 1989)

Pendidikan, Departemen, Pusat Bahasa Kamus Besar Bahasa Indonesia, (Jakarta: PT Gramedia, 2008)

https:/id.wikipedia.org/wiki/Patologi, diakses Bima, 20 September 2018, Pukul: 10:23 AM Wita.

Psikologisosiyal.blogspot.com/2016/08/pengertian-patologi-sosialmenurut para. html, diakses Bima, 20 September 2018 Pukul: 10:53 AM Wita.

Soekanto, Soerjono, Sosiologi Suatu Pengantar, (Jakarta: Rajawali Pers, 2012)

https://ayobelajarpemasaran.blogspot.com/2018/02/penyakit-sosialpengertian macam. html, diakser tanggal 11 Oktober 2018.

Departemen Agama RI, Al-Qur'an dan Terjemahannya, Surabaya: CV Fajar Mulya)

Rohman, Abid, Patologi Sosial Perspektif Al-Qur'an, Kajian Tafsir Tematik Sosiologi, (Uinsby, Jurnal pdf)

Sangaji Jurnal Pemikiran Syariah dan Hukum 